\title{
Small-animal PET imaging of the type 1 and type 2 cannabinoid receptors in a photothrombotic stroke model
}

\author{
Caroline Vandeputte • Cindy Casteels • Tom Struys • \\ Michel Koole • Daisy van Veghel • Nele Evens • \\ Anneleen Gerits • Tom Dresselaers • Ivo Lambrichts • \\ Uwe Himmelreich • Guy Bormans • Koen Van Laere
}

Received: 30 April 2012 / Accepted: 26 July 2012 /Published online: 16 August 2012

(C) Springer-Verlag 2012

\begin{abstract}
Purpose Recent ex vivo and pharmacological evidence suggests involvement of the endocannabinoid system in the pathophysiology of stroke, but conflicting roles for type 1 and 2 cannabinoid receptors $\left(\mathrm{CB}_{1}\right.$ and $\left.\mathrm{CB}_{2}\right)$ have been suggested. The purpose of this study was to evaluate $\mathrm{CB}_{1}$ and $\mathrm{CB}_{2}$ receptor binding over time in vivo in a rat photothrombotic stroke model using PET.

Methods $\mathrm{CB}_{1}$ and $\mathrm{CB}_{2}$ microPET imaging was performed at regular time-points up to 2 weeks after stroke using $\left[{ }^{18} \mathrm{~F}\right]$ MK-9470 and $\left[{ }^{11} \mathrm{C}\right]$ NE40. Stroke size was measured using MRI at 9.4 T. Ex vivo validation was performed via immunostaining for $\mathrm{CB}_{1}$ and $\mathrm{CB}_{2}$. Immunofluorescent double
\end{abstract}

C. Vandeputte $\cdot$ C. Casteels $\cdot$ M. Koole $\cdot$ A. Gerits $\cdot$ K. Van Laere Division of Nuclear Medicine, KU Leuven,

Leuven, Belgium

C. Vandeputte $\cdot$ C. Casteels $\cdot$ M. Koole $\cdot$ D. van Veghel $\cdot$

N. Evens $\cdot$ A. Gerits $\cdot$ T. Dresselaers $\cdot$ U. Himmelreich •

G. Bormans $\cdot \mathrm{K}$. Van Laere

Molecular Small Animal Imaging Center, MoSAIC, KU Leuven,

Leuven, Belgium

\section{T. Struys $\cdot$ I. Lambrichts}

Laboratory of Histology, Biomedical Research Institute,

Hasselt University,

Hasselt, Belgium

T. Struys $\cdot$ T. Dresselaers $\cdot$ U. Himmelreich

Biomedical NMR Unit, KU Leuven,

Leuven, Belgium

D. van Veghel · N. Evens · G. Bormans

Laboratory of Radiopharmacy, KU Leuven,

Leuven, Belgium

K. Van Laere $(\bowtie)$

Division of Nuclear Medicine, UZ Leuven,

Herestraat 49, E901,

3000 Leuven, Belgium

e-mail: koen.vanlaere@uzleuven.be stainings were also performed with markers for astrocytes (GFAP) and macrophages/microglia (CD68).

Results $\left[{ }^{18} \mathrm{~F}\right] \mathrm{MK}-9470$ PET showed a strong increase in $\mathrm{CB}_{1}$ binding $24 \mathrm{~h}$ and $72 \mathrm{~h}$ after stroke in the cortex surrounding the lesion, extending to the insular cortex $24 \mathrm{~h}$ after surgery. These alterations were consistently confirmed by $\mathrm{CB}_{1}$ immunohistochemical staining. $\left[{ }^{11} \mathrm{C}\right] \mathrm{NE} 40$ did not show any significant differences between stroke and sham-operated animals, although staining for $\mathrm{CB}_{2}$ revealed minor immunoreactivity at 1 and 2 weeks after stroke in this model. Both $\mathrm{CB}_{1}{ }^{+}$and $\mathrm{CB}_{2}{ }^{+}$cells showed minor immunoreactivity for $\mathrm{CD} 68$.

Conclusion Time-dependent and regionally strongly increased $\mathrm{CB}_{1}$, but not $\mathrm{CB}_{2}$, binding are early consequences of photothrombotic stroke. Pharmacological interventions should primarily aim at $\mathrm{CB}_{1}$ signalling as the role of $\mathrm{CB}_{2}$ seems minor in the acute and subacute phases of stroke.

Keywords $\mathrm{CB}_{1}$ receptor $\cdot \mathrm{CB}_{2}$ receptor $\cdot$ Positron emission tomography $\cdot$ Photothrombotic stroke $\cdot\left[{ }^{18} \mathrm{~F}\right] \mathrm{MK}-9470$.

$\left[{ }^{11} \mathrm{C}\right] \mathrm{NE} 40$

\section{Introduction}

Cerebral ischaemia or stroke is one of the leading causes of complex chronic disability worldwide and has a high mortality rate [1]. The associated reduction in oxygen supply to the brain is usually the result of thrombotic or embolic middle cerebral artery occlusion (MCAO) or occlusion of one of its branches [2]. Most of the available drugs target the penumbra, which has been defined as brain tissue that is functionally impaired but potentially salvageable if treated in time [3]. Unfortunately, there is just a small time window of opportunity so that most of the drugs that work in the acute phase are ineffective if administered more than $6 \mathrm{~h}$ 
after cerebral ischaemia [4]. Hence, elaborate research and drug development for stroke are indispensable.

There is a large amount of ex vivo evidence suggesting the involvement of the endocannabinoid system in cerebral ischaemia as it acts as a modulator of homeostasis and pathological response $[5,6]$. The endocannabinoid system consists of the type 1 cannabinoid receptor $\left(\mathrm{CB}_{1}\right)$, which is predominantly expressed in the brain, and the type 2 cannabinoid receptor $\left(\mathrm{CB}_{2}\right)$, which is mainly expressed in immune cells. Other compounds are endogenous cannabinoids, such as $\mathrm{N}$ arachidonoyl ethanolamide and 2-arachidonoyl-glycerol, and proteins responsible for their synthesis, transport and degradation $[7,8]$.

It has been suggested that cannabinoid agonists protect cortical neurons from ischaemic injury through interaction with $\mathrm{CB}_{1}$, which occurs as early as $2 \mathrm{~h}$ and persists for at least $72 \mathrm{~h}$ after surgery [9]. In $\mathrm{CB}_{1}$ knockout mice, mortality from permanent focal cerebral ischaemia is increased, infarct size and neurological deficits after transient focal cerebral ischaemia are more severe, cerebral blood flow in the ischaemic penumbra during reperfusion is reduced and NMDA neurotoxicity is increased compared to wild-type mice [10].

Although these studies support a protective effect of $\mathrm{CB}_{1}$ activation, contradictory new data indicate neuroprotective effects of $\mathrm{CB}_{1}$ blockade. Berger et al. have shown that administration of the $\mathrm{CB}_{1}$ antagonist SR141716A reduces infarct size by approximately $40 \%$ [11]. In addition, Zhang et al. have demonstrated that exogenous selective $\mathrm{CB}_{2}$ agonists reduce infarct volume and improve motor function in a mouse cerebral ischaemia/reperfusion model. This progress is associated with decreased leucocyte/endothelial cell interactions. Moreover, the combination of a $\mathrm{CB}_{1}$ antagonist (SR141716) and a $\mathrm{CB}_{2}$ agonist (O-1966) provided an even higher level of protection in ischaemia by increasing the regional cerebral blood flow during ischaemia $[12,13]$. Furthermore, Murikinati et al. showed that administration of the $\mathrm{CB}_{2}$ agonist JWH-133 decreases infarct size in a mouse model of ischaemic stroke by inhibiting neutrophil recruitment to the brain [14]. $\mathrm{CB}_{2}$ is mostly expressed in immune cells and may have an important influence on stroke-induced inflammatory reactions $[12,15]$.

Despite the efforts of many research groups to characterize the expression of both $\mathrm{CB}_{1}$ and $\mathrm{CB}_{2}$ in stroke ex vivo, their exact and relative role in the pathophysiology of stroke remains unclear. The development of high-affinity and selective radioligands for in vivo brain $\mathrm{CB}_{1}$ and $\mathrm{CB}_{2}$ quantification opens new perspectives in this context.

In this study, changes in $\mathrm{CB}_{1}$ and $\mathrm{CB}_{2}$ after cerebral ischaemia were investigated quantitatively and longitudinally in a photothrombotic stroke model in rats. $\mathrm{CB}_{1}$ and $\mathrm{CB}_{2}$ expression were measured by small-animal PET with $\left[{ }^{18} \mathrm{~F}\right]$ MK-9470 and $\left[{ }^{11} \mathrm{C}\right] \mathrm{NE} 40$, respectively [16-18], in correlation with morphological measures of stroke extent and severity.

\section{Materials and methods}

Animals and surgery

Animals were housed under a $12 \mathrm{~h}$ light/12 h dark cycle with free access to food and water. All animal experiments were performed in accordance with national and international regulations, and approved by the local animal care and ethics commission. Animals scanned using $\left[{ }^{18} \mathrm{~F}\right] \mathrm{MK}-9470$ $\left(\mathrm{CB}_{1}\right.$ imaging) were anaesthetized before surgery with a mixture of ketamine (Ketalar ${ }^{\circledR}, 60 \mathrm{mg} / \mathrm{kg}$; Pfizer, Brussels, Belgium) and medetomidin (Domitor ${ }^{\mathbb{B}}, 0.4 \mathrm{mg} / \mathrm{kg}$ intraperitoneal; Pfizer). Anaesthesia was reversed with atipamezol (Antisedan $^{\circledR}, 1 \mathrm{mg} / \mathrm{kg}$ intraperitoneal; Orion Pharma, Newbury, UK) at the end of surgery. Animals scanned using $\left[{ }^{11} \mathrm{C}\right] \mathrm{NE} 40\left(\mathrm{CB}_{2}\right.$ imaging $)$ were anaesthetized with $2-$ $2.5 \%$ isoflurane $/ \mathrm{O}_{2}$ gas anaesthesia (Halocarbon Products Corporation, River Edge, NJ) through a face mask during surgery.

For logistic reasons in tracer production, the study design included two separate groups of animals for the $\mathrm{CB}_{1}$ and $\mathrm{CB}_{2}$ scans. In total, 45 male Wistar rats were investigated. The first group $\left(\mathrm{CB}_{1}\right.$ imaging) comprised 218 -week-old rats (Janvier, Le Genest Saint Isle, France), of which 14 received a photothrombotic cortical stroke and 7 received a sham operation. The second group $\left(\mathrm{CB}_{2}\right.$ imaging $)$ comprised 16 10 -week-old rats (Janvier, and for logistic reasons concerning animal delivery, Harlan, Laboratories, Horst, The Netherlands), of which 9 received a cortical stroke and 7 received a sham operation. A final group of 8 Wistar rats (Janvier), anaesthetized with $2-2.5 \%$ isoflurane $/ \mathrm{O}_{2}$ gas anaesthesia (Halocarbon Products Corporation), was added for histological analysis of the stroke animals. The experimental outline is given in Fig. 1. Functional imaging of brain $\mathrm{CB}_{1}$ and $\mathrm{CB}_{2}$ receptor availability was performed in stroke rats and sham-operated rats before surgery, and $24 \mathrm{~h}$, $72 \mathrm{~h}$ and 1 week after surgery. For acute assessment $\mathrm{CB}_{1}$ and $\mathrm{CB}_{2}$ imaging was included at $3.5 \mathrm{~h}$ and $1-2 \mathrm{~h}$, respectively. For the $\mathrm{CB}_{2}$ imaging group, an extra time-point was added at 2 weeks after surgery as inflammatory cells participate in tissue remodelling and reconstruction following injury that takes place in the weeks after stroke [19].

Cortical ischaemia (stroke model) was induced by photothrombotic injury [20]. After intravenous injection of the photosensitizer Rose Bengal $(20 \mathrm{mg} / \mathrm{kg}$; Sigma-Aldrich, St. Louis, MO), an area of exposed intact skull was irradiated for 20 min with green light (wavelength $540 \mathrm{~nm}$, bandwidth $80 \mathrm{~nm}$ ) from a xenon lamp (model L-4887; Hamamatsu Photonics, Hamamatsu City, Japan) with heat-absorbing 
Fig. 1 Experimental design for $\mathrm{CB}_{1}\left(\left[{ }^{18} \mathrm{~F}\right] \mathrm{MK}-9470\right)$ (a) and $\mathrm{CB}_{2}\left(\left[{ }^{11} \mathrm{C}\right] \mathrm{NE} 40\right)(\mathbf{b})$ microPET imaging of photothrombotic stroke model rats a

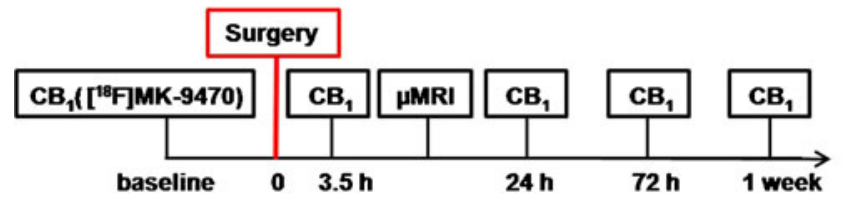

b

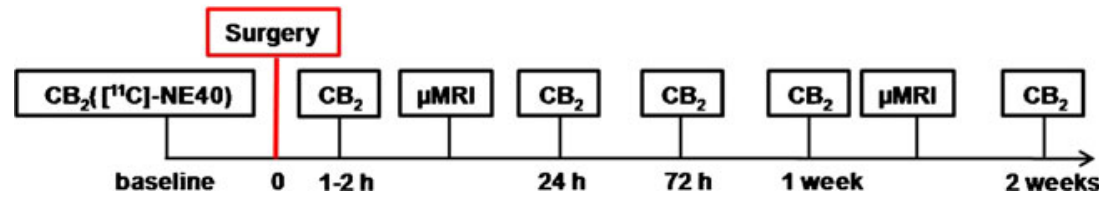

and green filters. The radiation with an intensity of $0.68 \mathrm{~W} /$ $\mathrm{cm}^{2}$ was directed with a 3-mm optical fibre placed on the skull above the right sensorimotor cortex next to bregma. The photooxidation causes endothelial damage, platelet activation, and finally vascular occlusion [20]. The shamoperated animals underwent the same operation procedure except for irradiation with green light.

\section{Radiotracer preparation}

$\mathrm{CB}_{1}$ imaging was done using the radioligand $\left[{ }^{18} \mathrm{~F}\right] \mathrm{MK}-9470$ ( $N$-[2-(3-cyano-phenyl)-3-(4-(2- $\left[{ }^{18} \mathrm{~F}\right]$ fluoroethoxy)-phenyl)1-methylpropyl]-2-(5-methyl-2-pyridyloxy)-2-methylproponamide), which has a high specificity and high affinity for $\mathrm{CB}_{1}\left(K_{\mathrm{i}} 0.7 \mathrm{nM}\right)[16]$. The precursor for $\left[{ }^{18} \mathrm{~F}\right] \mathrm{MK}-9470$ was obtained from Merck Research Laboratories (MRL, West Point, PA). Radiolabelling was performed on-site by alkylation of the precursor with $2-\left[{ }^{18} \mathrm{~F}\right]$ fluoroethylbromide. $\mathrm{CB}_{2}$ imaging was performed with the radioligand $\left[{ }^{11} \mathrm{C}\right] \mathrm{NE} 40(2-$ oxo-7-[ $\left.{ }^{11} \mathrm{C}\right]$ methoxy-8-butyloxy-1,2-dihydroquinoline-3carboxylic acid cyclohexylamide). Radiosynthesis of $\left[{ }^{11} \mathrm{C}\right]$ NE40 ( $\left.\mathrm{K}_{\mathrm{i}} 9.6 \mathrm{nM}\right)$ was performed as previously described [17]. The specific activity ranges of $\left[{ }^{18} \mathrm{~F}\right] \mathrm{MK}-9470$ and $\left[{ }^{11} \mathrm{C}\right] \mathrm{NE} 40$ were $53-320 \mathrm{GBq} / \mu \mathrm{mol}$ and $37-222 \mathrm{GBq} /$ $\mu \mathrm{mol}$, respectively.

Prior to small-animal PET imaging, rats were anaesthetized using $3 \%$ isoflurane in $2.0 \mathrm{l} / \mathrm{min}$ oxygen. The effect of this anaesthetic on the uptake of $\left[{ }^{18} \mathrm{~F}\right] \mathrm{MK}-9470$ in rat brain has been described elsewhere [21]. Tail veins were catheterized for injection of $\left[{ }^{18} \mathrm{~F}\right] \mathrm{MK}-9470(22.13 \pm 1.67 \mathrm{MBq}$, $\left.6.93 \times 10^{-5}-4.24 \times 10^{-4} \mu \mathrm{mol}\right)$ or $\left[{ }^{11} \mathrm{C}\right] \mathrm{NE} 40(46.25 \pm$ $\left.9.18 \mathrm{MBq}, 2.08 \times 10^{-4}-1.25 \times 10^{-3} \mu \mathrm{mol}\right)$.

PET data acquisition and reconstruction

Small-animal PET imaging was performed using a FOCUS 220 tomograph (Siemens/Concorde Microsystems, Knoxville, TN), which has a nominal transaxial resolution of $1.35 \mathrm{~mm}$ full-width at half-maximum. Data were acquired in a $128 \times 128 \times 95$ matrix with pixel widths of $0.475 \mathrm{~mm}$ and $1.898 \mathrm{~mm}$ for $\left[{ }^{18} \mathrm{~F}\right] \mathrm{MK}-9470$ and $\left[{ }^{11} \mathrm{C}\right] \mathrm{NE} 40$ imaging, respectively, and a slice thickness of $0.796 \mathrm{~mm}$. $\left[{ }^{18} \mathrm{~F}\right] \mathrm{MK}$ 9470 measurements were obtained over 20 min starting $1 \mathrm{~h}$ after injection after overnight fasting of the animals. Specific binding of $\left[{ }^{18} \mathrm{~F}\right] \mathrm{MK}-9470$ to $\mathrm{CB}_{1}$ was confirmed by a blocking imaging study in one animal. Approximately $1 \mathrm{~h}$ before injection of the radioligand, the animal was treated orally with SR141716A (Acomplia ${ }^{\circledR}$, Sanofi-Aventis, Diegem, Belgium), a selective $\mathrm{CB}_{1}$ antagonist, at a high blocking dose $(10 \mathrm{mg} / \mathrm{kg})[22]$. $\left[{ }^{11} \mathrm{C}\right] \mathrm{NE} 40$ binding was measured via a 60-min dynamic acquisition immediately after intravenous injection of approximately $37 \mathrm{MBq}$ of the tracer. Since three animals were scanned simultaneously in the $\mathrm{CB}_{2}$ group, attenuation correction was performed using a rotating ${ }^{57}$ Co source (10-min scan). No attenuation correction was performed for the other animals as they were scanned individually. Data were reconstructed using filtered backprojection.

\section{MR imaging}

MRI data were acquired $24 \mathrm{~h}$ after surgery in the $\mathrm{CB}_{1}$ group, and $24 \mathrm{~h}$ and between 8 and 11 days after surgery in the $\mathrm{CB}_{2}$ group. Rats were anaesthetized with isoflurane (Halocarbon, River Edge, NJ) in oxygen ( $4 \%$ for induction, $1.5-2.5 \%$ for maintenance). Breathing rate and body temperature were monitored and maintained at 55-80 $\mathrm{min}^{-1}$ and $37 \pm 1{ }^{\circ} \mathrm{C}$, respectively. MR images were acquired using a Bruker Biospec 9.4-T small-animal MR scanner (horizontal bore $20 \mathrm{~cm}$; Bruker BioSpin, Ettlingen, Germany) equipped with actively shielded gradients $(600 \mathrm{mT} / \mathrm{m})$. Images were recorded using a 7-cm linear resonator (Bruker BioSpin) combined with an actively decoupled dedicated rat brain surface coil (Rapid Biomedical, Rimpar, Germany). $\mathrm{T}_{2}$ maps were acquired using a multislice/multiecho (MSME) sequence with the following parameters: ten echo time increments of $10 \mathrm{~ms}$, TR $2,252 \mathrm{~ms}$, FOV $40 \times 40 \mathrm{~mm}$, inplane resolution $156 \mu \mathrm{m}, 20$ interlaced slices of thickness $0.4 \mathrm{~mm}$. High-resolution three-dimensional MR images were acquired using either a gradient-echo sequence 
(FLASH; TR $100 \mathrm{~ms}$, TE $12 \mathrm{~ms}$, flip angle 30 , FOV $40 \times$ $26 \times 13 \mathrm{~mm}$, isotropic resolution $100 \mu \mathrm{m}$ ) or a spin echo sequence (TurboRARE; TR 1,000 ms, TE $49 \mathrm{~ms}$, FOV $30 \times$ $30 \times 12 \mathrm{~mm}$, resolution $100 \times 150 \times 150 \mu \mathrm{m}, 8$ days after surgery). Stroke volumes were manually delineated and quantified on transverse MSME images using PMOD 3.1. Three-dimensional MRI was used for coregistration with PET images to delineate stroke lesions.

\section{Image processing}

Parametric images based on standardized uptake values (SUV; activity concentration in megabecquerels per millilitre $\times$ body mass in grams/injected dose in megabecquerels) were generated as a measure of $\mathrm{CB}_{1}$ binding [16, 23-25]. Relative uptake of $\left[{ }^{18} \mathrm{~F}\right] \mathrm{MK}-9470$ was expressed as SUV normalized on the whole-brain SUV.

Parametric $\mathrm{CB}_{2}$ binding potential (BP) images, representing $\mathrm{CB}_{2}$ availability, were constructed using a reference tissue model. The contralateral cortex was used as the reference tissue instead of the cerebellum, since $\mathrm{CB}_{2}$ is expressed by a subpopulation of microglia in the cerebellum [26], and the Logan graphical method was used implemented in PMOD 3.1.

To obtain maximal use of $\left[{ }^{18} \mathrm{~F}\right] \mathrm{MK}-9470$ image information, images were analysed on a voxel-by-voxel basis using SPM2 [27]. This methodology allows reporting results as coordinates directly corresponding to the Paxinos coordinate system of rat brain. Parametric $\left[{ }^{18} \mathrm{~F}\right] \mathrm{MK}-9470$ images were analysed by statistical parametric mapping (SPM) both in a multisubject design using subjects (stroke vs. sham) $\times$ conditions (baseline, $3.5 \mathrm{~h}, 24 \mathrm{~h}, 72 \mathrm{~h}$ and 1 week after surgery; note that the 3.5-h time-point included a different set of different animals). Spatially normalized images were masked to remove extracerebral signal. All images were smoothed with an isotropic gaussian kernel of $1.6 \mathrm{~mm}$.

For analysis of absolute $\left[{ }^{18} \mathrm{~F}\right] \mathrm{MK}-9470$ receptor binding, no proportional scaling was used and an analysis threshold of 0.8 of the mean image intensity was applied. To study regional $\left[{ }^{18} \mathrm{~F}\right] \mathrm{MK}-9470$ uptake, proportional scaling was used. To minimize false-positive findings, T-map data were interrogated at a peak level of $p_{\text {height }}<0.001$ (uncorrected) and extent threshold $k_{\mathrm{E}}>200$ voxels $\left(1.6 \mathrm{~mm}^{3}\right)$, as described previously [28]. Only those clusters that were significant at the $p_{\text {cluster }}<0.05$ (corrected) level were considered.

Histological assessment of stroke lesions

At each time-point after surgery at least two rats were killed by an intraperitoneal injection of pentobarbital followed by transcardial perfusion with $4 \%$ paraformaldehyde in phosphatebuffered saline (PBS). The brain was removed, preserved in $4 \%$ paraformaldehyde in PBS, then put through a dehydrating series of graded concentrations of alcohol, and finally embedded in paraffin. Paraffin sections $(5-8 \mu \mathrm{m})$ were made and attached to SuperFrost Plus glass slides (Menzel, Braunschweig, Germany). Sections were deparaffinized with xylol, followed by decreasing concentrations of alcohol, and then washed in PBS. Prior to immunohistochemical staining, antigens were retrieved (sections were microwaved in a $10 \mathrm{mM}$ citrate buffer at $\mathrm{pH} 6.0$ ), and endogenous peroxidase activity was quenched with $0.5 \% \mathrm{H}_{2} \mathrm{O}_{2}$.

\section{Diaminobenzidine staining}

Nonspecific binding sites were blocked with $3 \%$ normal goat serum. Sections were then either incubated with a rabbit anti$\mathrm{CB}_{1}$ polyclonal antibody (Abcam, Cambridge, UK) at a dilution of $1 / 100$ in $\mathrm{PBS}$ or a rabbit anti-CB $\mathrm{CB}_{2}$ polyclonal antibody (Cayman Chemical, MI) at a dilution of 1/150 in PBS for $1 \mathrm{~h}$. Both antibodies are immunoreactive towards rat antigens. Sections were then incubated with a peroxidase-labelled polymer conjugated to a goat antirabbit secondary antibody for 30 min (Envision System ${ }^{\circledR}$; DakoCytomation, Glostrup, Denmark). Immunoreactivity was visualized with 3,3'-diaminobenzidine. Sections were counterstained with Mayer's haematoxylin, coverslipped, and examined under a Mirax Desk digital microscope (Zeiss, Oberkochen, Germany). Negative controls were negative and positive controls stained positive for each antibody (data not shown).

\section{Immunofluorescent double staining}

Nonspecific binding sites were blocked with $10 \%$ normal donkey serum for $30 \mathrm{~min}$. Sections were then incubated with a rabbit anti- $\mathrm{CB}_{1}$ polyclonal antibody (Abcam, Cambridge, $\mathrm{UK}$ ) at a dilution of $1 / 100$ in PBS or a rabbit anti-CB $\mathrm{CB}_{2}$ polyclonal antibody (Cayman Chemical, MI) at a dilution of 1/150 in PBS combined with a mouse anti-CD68 monoclonal antibody (Abcam) at a dilution of 1/100 in PBS or a mouse antiGFAP monoclonal antibody (Abcam) at a dilution of 1/400 in PBS for $1.5 \mathrm{~h}$. All antibodies are immunoreactive towards rat antigens. Sections were then incubated with both an Alexa Fluor 488-labelled donkey antirabbit and an Alexa Fluor 555 donkey antimouse secondary antibody for $45 \mathrm{~min}$ at a dilution of 1/1,000 in PBS (Invitrogen, Carlsbad, CA). Following washing with PBS, cell nuclei were visualized by staining with 4',6-diamidino-2-phenylindole dihydrochloride (Invitrogen) and again washed with normal water followed by MilliQ water. Finally, sections were coverslipped using fluorescence mounting medium (DakoCytomation, Glostrup, Denmark) and examined using AxioVision (Zeiss, Oberkochen, Germany).

\section{Statistics}

$\left[{ }^{11} \mathrm{C}\right]$ NE40 BP images were analysed statistically with Statistica v. 8.0 (StatSoft, Tulsa, OK). Significance was 
accepted at the $95 \%$ probability level. Data are expressed as means $\pm \mathrm{SD}$.

\section{Results}

Photothrombotic stroke lesion

All animals except one in the $\mathrm{CB}_{2}$ group survived surgery. In the $\mathrm{CB}_{1}$ group, the average lesion volume was $12.9 \pm$ $6.1 \mathrm{~mm}^{3}$ (range of $21.8 \mathrm{~mm}^{3}$ ) as determined by highresolution three-dimensional $\mathrm{MR}$ imaging. In the $\mathrm{CB}_{2}$ group, the average lesion volume was $18.5 \pm 9.0 \mathrm{~mm}^{3}$ (range of $22.9 \mathrm{~mm}^{3}$ ). There was no significant difference in stroke volume between the two groups.

\section{$\mathrm{CB}_{1}$ binding}

Absolute $\left[{ }^{18} \mathrm{~F}\right] \mathrm{MK}-9470 \mathrm{SUV}$ values were not significantly different between stroke and sham-operated animals at all time-points measured. Regional relative analysis, however, showed that $\mathrm{CB}_{1}$ binding was locally higher in stroke animals than in sham-operated animals around the lesion: in stroke animals $\mathrm{CB}_{1}$ binding in the ipsilateral sensorimotor cortex was $28 \pm 9 \%$ higher $24 \mathrm{~h}\left(p=1.3 \times 10^{-7}\right)$ and $26 \pm 8 \%$ higher $72 \mathrm{~h}$ $\left(p=6.4 \times 10^{-6}\right)$ after surgery than in sham-operated animals. Additionally, $\mathrm{CB}_{1}$ binding was $17 \pm 8 \%$ higher $(p=5.0 \times$ $10^{-5}$ ) in the ipsilateral insular cortex in stroke rats than in sham-operated rats $24 \mathrm{~h}$ after surgery. At $3.5 \mathrm{~h}$ and 1 week after surgery, no significant differences were measured between the two groups. Decreases in $\mathrm{CB}_{1}$ binding were measured inside the necrotic lesions $24 \mathrm{~h}$ and $72 \mathrm{~h}$ after surgery compared to baseline (Fig. 2). Statistical parametric maps of $\left[{ }^{18} \mathrm{~F}\right] \mathrm{MK}-9470$ are shown in Fig. 3 for $24 \mathrm{~h}$, for $72 \mathrm{~h}$ and for $3.5 \mathrm{~h} / 1$ week after surgery. Detailed cluster peak locations, intensity differences and $p$ values from the SPM analyses are shown in Table 1.

Since disruption of the blood-brain barrier is intrinsic to stroke and may lead to an increase in brain perfusion resulting in an aspecific increase in tracer uptake in the stroke area, specific binding of $\left[{ }^{18} \mathrm{~F}\right] \mathrm{MK}-9470$ to $\mathrm{CB}_{1}$ was confirmed by blocking the receptor with SR141716A in an animal $24 \mathrm{~h}$ after stroke [29]. After blocking with SR141716A $(10 \mathrm{mg} / \mathrm{kg}) 1 \mathrm{~h}$ before injection of $\left[{ }^{18} \mathrm{~F}\right]$ MK-9470, a uniform decrease of $\pm 30 \%$ in signal was observed in all brain regions including the stroke region, indicating a specific increased uptake of $\left[{ }^{18} \mathrm{~F}\right] \mathrm{MK}-9470$ around the stroke area. Figure 4 illustrates this decrease in tracer uptake compared to the average uptake of the tracer $24 \mathrm{~h}$ after stroke.
Fig. 2 Representative transverse, coronal and sagittal small-animal PET images of $\left[{ }^{18} \mathrm{~F}\right] \mathrm{MK}-9470$ tracer binding and MR images of a representative stroke animal. The images obtained at baseline, and $24 \mathrm{~h}, 72 \mathrm{~h}$ and 1 week after stroke are shown. The coloured bars indicate SUV values
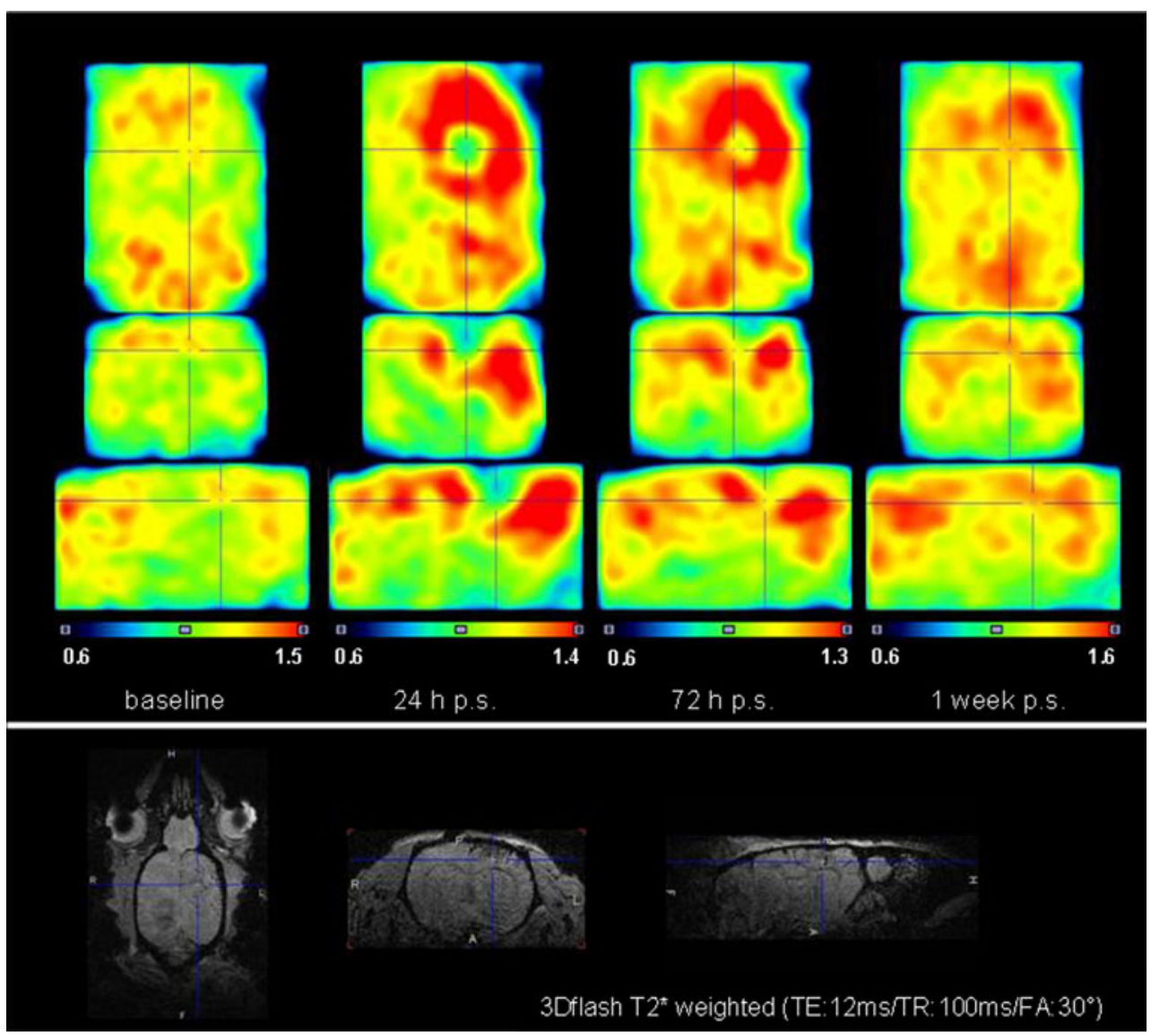
Fig. 3 Coronal brain sections showing overlays on the regions where statistically significant increases in relative $\left[{ }^{18} \mathrm{~F}\right] \mathrm{MK}-9470$ binding were observed in animals with a photothrombotic stroke compared to sham-operated animals (a) $24 \mathrm{~h}$ after surgery $\left(p_{\text {height }}<0.001\right.$ uncorrected), (b) $72 \mathrm{~h}$ after surgery $\left(p_{\text {height }}<\right.$ 0.001 uncorrected) and (c) $3.5 \mathrm{~h}$ and 1 week after surgery $\left(p_{\text {height }}\right.$ $<0.05$ uncorrected). Significance is shown with a $T$ statistic colour scale, which corresponds to the level of significance at the voxel level. The distance between the sections is $1.00 \mathrm{~mm}$ with the position relative to bregma at the top left of the images. $\mathrm{CB}_{1}$ increases are mainly located in the region around the lesions (sensorimotor cortex) $24 \mathrm{~h}$ and $72 \mathrm{~h}$ after surgery and in the ipsilateral insular cortex $24 \mathrm{~h}$ after surgery. No significant $\mathrm{CB}_{1}$ changes are seen $3.5 \mathrm{~h}$ or 1 week after surgery

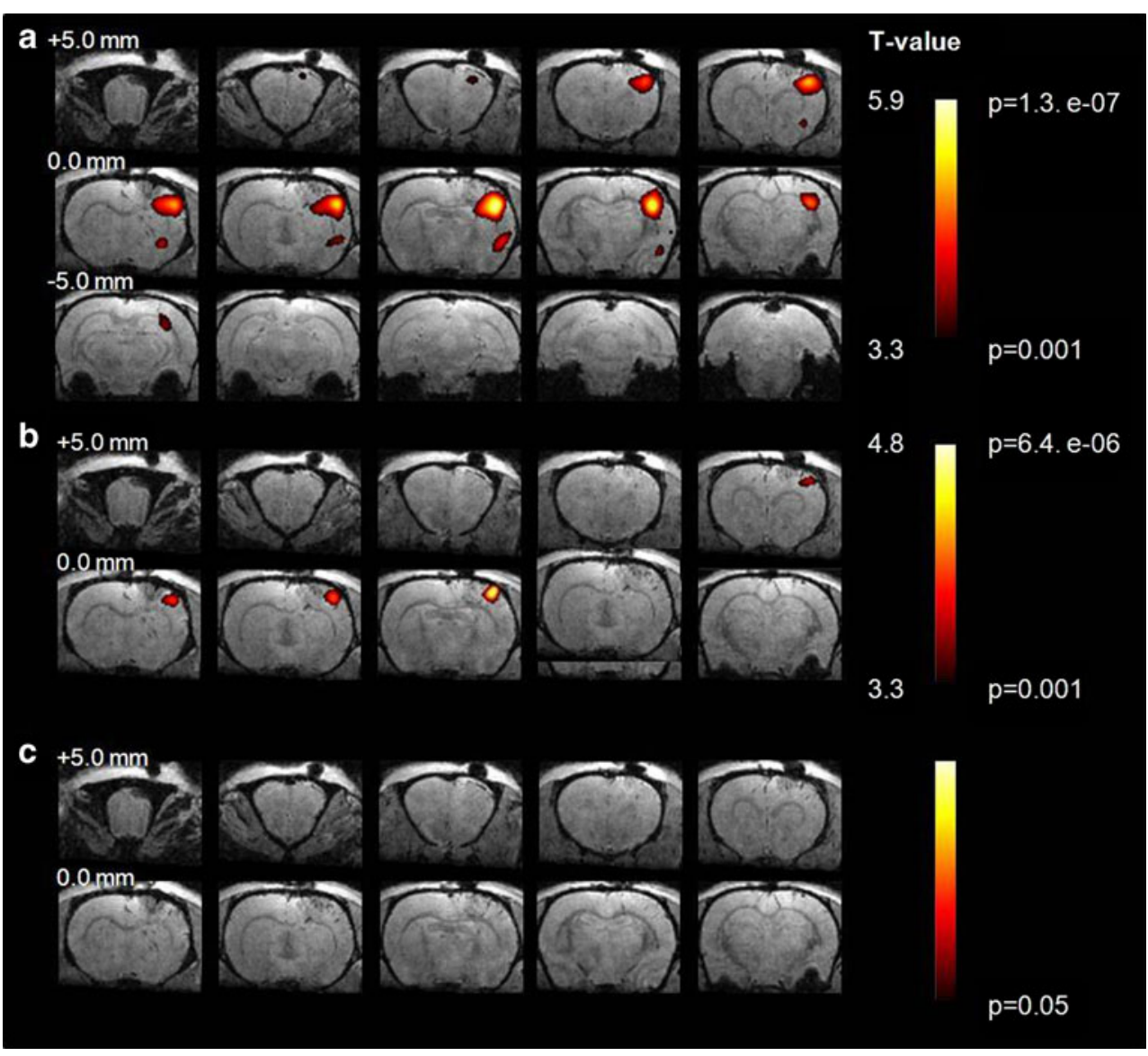

\section{$\mathrm{CB}_{2}$ binding}

At none of the time-points measured was a significant difference in $\left[{ }^{11} \mathrm{C}\right] \mathrm{NE} 40 \mathrm{BP}$ detected between the stroke and shamoperated animals, either in the stroke area or in other cortical sides of the animals. Figure 5 a shows the $\left[{ }^{11} \mathrm{C}\right] \mathrm{NE} 40$ binding before surgery and $24 \mathrm{~h}, 72 \mathrm{~h}, 1$ week and 2 weeks after surgery in a representative stroke model. No significant uptake could be distinguished at either time-point. Figure $5 \mathrm{~b}$ shows the average time-activity curves for both the ipsilateral and the contralateral region of the stroke animals 1 week after surgery. Data were similar at all other time-points measured in both stroke and sham-operated animals.

\section{Histological analysis}

Animals were killed at different time-points (1-2 h, $3.5 \mathrm{~h}$, 24 h, 72 h, 1 week and 2 weeks after stroke; two or three per time-point). Brain slices were stained for both $\mathrm{CB}_{1}$ and $\mathrm{CB}_{2}$ and counterstained with haematoxylin (Fig. 6). Between $24 \mathrm{~h}$ and $72 \mathrm{~h}$ after surgery, $\mathrm{CB}_{1}{ }^{+}$cells accumulated around the border of the photothrombotic lesion corresponding to

Table 1 Peak locations for the clusters in the group comparisons at $p_{\text {height }} \leq 0.001$ uncorrected, $k_{\text {ext }}>200$ (categorical analysis, $\left[{ }^{18} \mathrm{~F}\right] \mathrm{MK}-9470$, stroke $>$ sham)

\begin{tabular}{|c|c|c|c|c|c|c|c|c|c|}
\hline \multirow[t]{2}{*}{ Time after surgery (h) } & \multicolumn{2}{|c|}{ Cluster level } & \multicolumn{2}{|c|}{ Voxel level } & \multicolumn{4}{|l|}{ Structure } & \multirow[t]{2}{*}{ Location } \\
\hline & $p_{\text {corr }}$ & $k_{\mathrm{E}}$ & $T$ & $p_{\text {uncorr }}$ & Difference $(\%)$ & $x$ & $y$ & $z$ & \\
\hline \multirow[t]{3}{*}{24} & $<0.001$ & 6,325 & $\begin{array}{l}5.94 \\
5.05\end{array}$ & $\leq 0.001$ & +28.2 & $\begin{array}{l}-5.2 \\
-4.4\end{array}$ & $\begin{array}{l}-2.4 \\
1.2\end{array}$ & $\begin{array}{l}-4.0 \\
-3.2\end{array}$ & $\begin{array}{l}\text { Around the lesion, i.e. } \\
\text { sensorimotor cortex }\end{array}$ \\
\hline & & & 3.40 & & & -1.8 & 3.8 & -2.6 & \\
\hline & $<0.001$ & 1,037 & $\begin{array}{l}4.22 \\
4.01\end{array}$ & $<0.001$ & +17.5 & $\begin{array}{l}-6.0 \\
-4.0\end{array}$ & $\begin{array}{l}-1.8 \\
0.2\end{array}$ & $\begin{array}{l}-7.6 \\
-8.0\end{array}$ & Insular cortex \\
\hline 72 & $<0.001$ & 1,398 & 4.83 & $<0.001$ & +26.2 & -5.0 & -2.4 & -2.0 & $\begin{array}{l}\text { Around the lesion, i.e. } \\
\text { sensorimotor cortex }\end{array}$ \\
\hline
\end{tabular}


Fig. 4 In vivo $\left[{ }^{18} \mathrm{~F}\right] \mathrm{MK}-9470$ microPET images in rats $24 \mathrm{~h}$ after stroke. a Average image of all stroke rats scanned $24 \mathrm{~h}$ after surgery. b $\left[{ }^{18} \mathrm{~F}\right] \mathrm{MK}-9470$ image acquired after blocking with SR141716A (10 mg/kg orally) approximately $1 \mathrm{~h}$ before injection of the radioligand. Blocking with SR141716A resulted in a decrease of $\pm 30 \%$ in all brain regions. The colour scale indicates SUV units. A predefined VOI map is overlain on the images

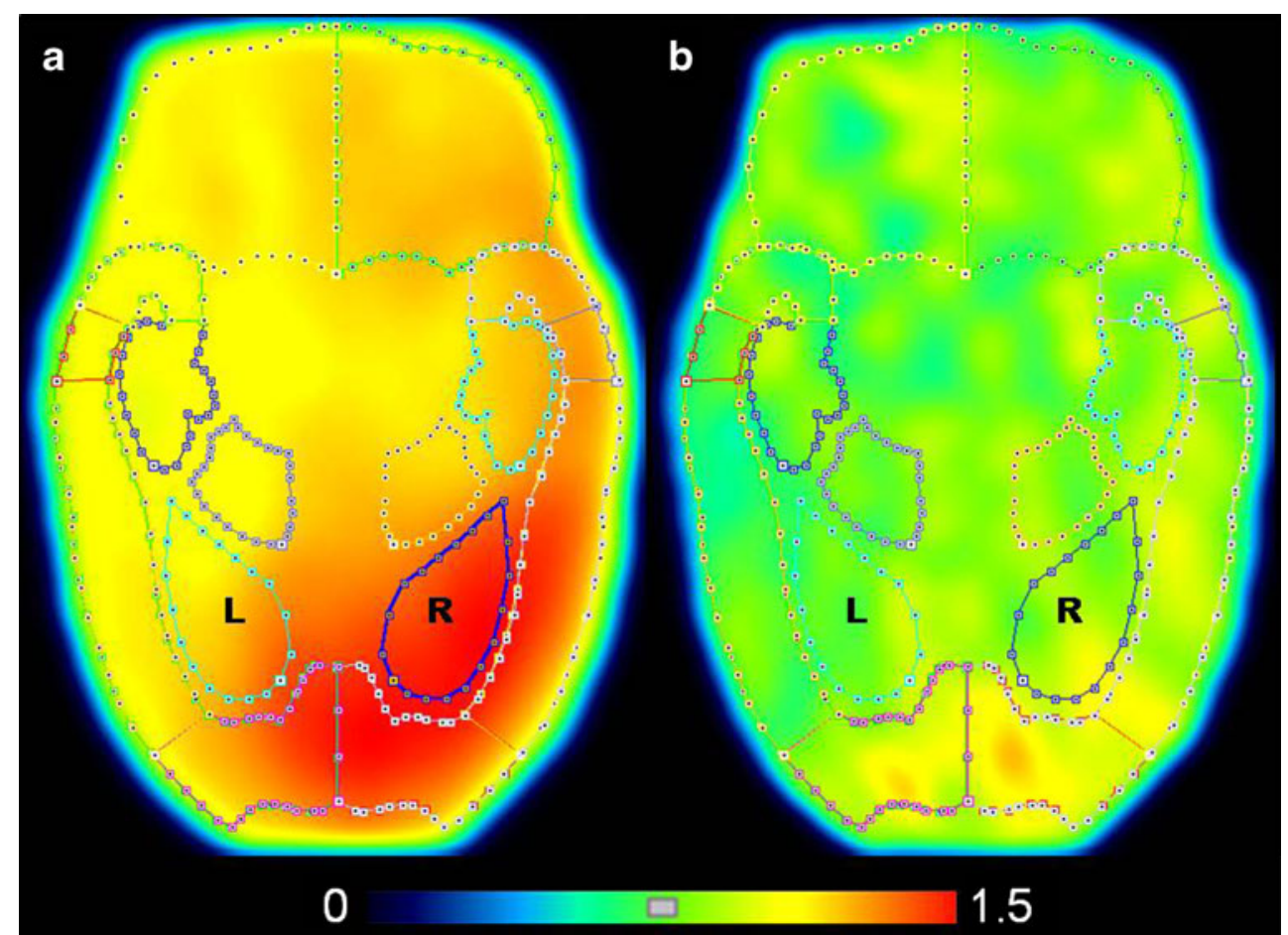

the uptake of $\left[{ }^{18} \mathrm{~F}\right] \mathrm{MK}-9470$ (Fig. 6a). No $\mathrm{CB}_{1}{ }^{+}$cells were seen in the lesion itself, nor in the insular cortex at these time-points. From 1 week after stroke, $\mathrm{CB}_{1}{ }^{+}$cells infiltrated into the inner part of the lesion resulting in abundant cells inside the lesion at 2 weeks (Fig. 6a). At 1-2 h, $24 \mathrm{~h}$ and $72 \mathrm{~h}$ after stroke, no $\mathrm{CB}_{2}{ }^{+}$cells could be seen beside the lesions, in accordance with the lack of specific $\left[{ }^{11} \mathrm{C}\right] \mathrm{NE} 40$ uptake at these time-points (Fig. 6b). A small amount of $\mathrm{CB}_{2}{ }^{+}$cells was seen 1 and 2 weeks after surgery in the border zone of the lesions (Fig. 6b).

Next, we characterized the $\mathrm{CB}_{1}{ }^{+}$and $\mathrm{CB}_{2}{ }^{+}$cells in more detail by double immunofluorescent staining with antibodies against $\mathrm{CB}_{1} / \mathrm{CB}_{2}$ and GFAP (marker for astrocytes) or CD68 (marker for activated macrophages and microglia). In the border of the lesions, none of the $\mathrm{CB}_{1}{ }^{+}$or $\mathrm{CB}_{2}{ }^{+}$cells were $\mathrm{GFAP}^{+}$, demonstrating that the $\mathrm{CB}_{1}{ }^{+}$or $\mathrm{CB}_{2}{ }^{+}$cells accumulating around the stroke region were not astrocytes (data not shown). A minority of the $\mathrm{CB}_{1}{ }^{+}$and $\mathrm{CB}_{2}{ }^{+}$cells stained positive for CD68 (Fig. 7).

\section{Discussion}

We characterized changes in both $\mathrm{CB}_{1}$ and $\mathrm{CB}_{2}$ for the first time in vivo in a rat model of stroke by small-animal PET using $\left[{ }^{18} \mathrm{~F}\right] \mathrm{MK}-9470$ and $\left[{ }^{11} \mathrm{C}\right] \mathrm{NE} 40$, respectively. $\left[{ }^{18} \mathrm{~F}\right] \mathrm{MK}-$ 9470 and $\left[{ }^{11} \mathrm{C}\right] \mathrm{NE} 40$ small-animal PET imaging is a unique noninvasive method for the in vivo evaluation of pathological changes in the endocannabinoid system in animal models of focal cerebral ischaemia, with potential translational value. Whole-brain characterization of $\mathrm{CB}_{1} / \mathrm{CB}_{2}$ in stroke could be used in the proof-of-principle mechanistic investigation of potential pharmacological treatment approaches [13].

$\left[{ }^{18} \mathrm{~F}\right] \mathrm{MK}-9470$ binding was subacutely increased in the region around the strokes by on average $28 \%$ at $24 \mathrm{~h}$, and remained increased by an average of $26 \% 72 \mathrm{~h}$ after surgery. No signal changes were observed at early timepoints (4 $\mathrm{h}$ after stroke). $\left[{ }^{18} \mathrm{~F}\right] \mathrm{MK}-9470 \mathrm{PET}$ is thus a promising in vivo tool for the study of the effects of new drugs that target the endocannabinoid system in the subacute phase after stroke [13]. The increased $\mathrm{CB}_{1}$ binding at these time-points was confirmed by immunohistochemical analysis. Histologically, at both time-points a large number of $\mathrm{CB}_{1}{ }^{+}$cells were detected around the border zone of stroke lesions. Jin et al. found induction of $\mathrm{CB}_{1} \mathrm{mRNA}$ in the boundary zone surrounding focal ischaemic brain lesions beginning $2 \mathrm{~h}$ and persisting for $72 \mathrm{~h}$ or more after ischaemia using western blot and immunohistochemistry [9]. Our findings are thus in line with those of this previous ex vivo study, although no increased $\mathrm{CB}_{1}$ binding was detected $3.5 \mathrm{~h}$ after stroke induction. Zhang et al. evaluated the expression of $\mathrm{CB}_{1}$ by real-time PCR in the ischaemic hemisphere in a mouse model with transient MCAO from $1 \mathrm{~h}$ after ischaemia [13]. $\mathrm{CB}_{1}$ mRNA levels were measured at different time-points up to $24 \mathrm{~h}$ after MCAO, and showed a maximal increase at $6 \mathrm{~h}$. There seems to be a delay between mRNA expression and increased binding observed in this model. 


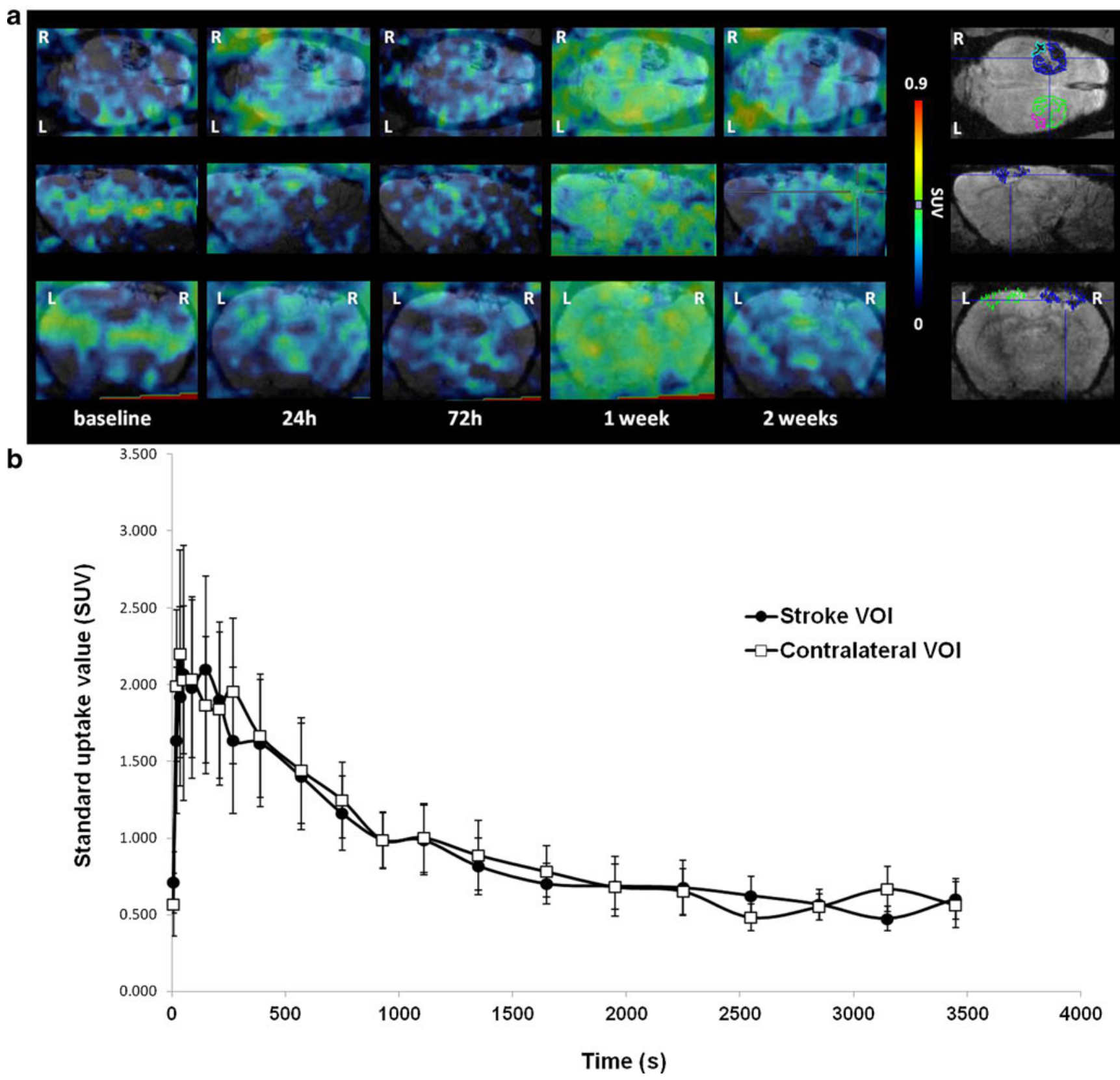

Fig. $5\left[{ }^{11} \mathrm{C}\right] \mathrm{NE} 40$ PET imaging in stroke rats. a Images in a representative animal obtained at baseline and $24 \mathrm{~h}, 72 \mathrm{~h}, 1$ week and 2 weeks after stroke (columns 1-5, respectively) coregistered with the corresponding MRI images (last column individual MR images of the same animal with VOIs delineated; top row, middle row and bottom

It has been suggested that an increase in $\mathrm{CB}_{1}$ has neuroprotective effects in several neuropathologies that could be mediated by $\mathrm{CB}_{1}$-induced presynaptic inhibition of glutamate release [30]. More specifically, there is a wellestablished association between $\mathrm{CB}_{1}$ and inhibition of $\mathrm{Ca}^{2+}$ channels that are linked to the release of the excitotoxic neurotransmitter glutamate [31]. Excitotoxicity is also one of the most important pathophysiological events in stroke, occurring very early after onset triggering acute tissue damage and a row transverse, sagittal and coronal views, respectively). b Average $\left[{ }^{11} \mathrm{C}\right] \mathrm{NE} 40$ uptake in rats 1 week after surgery. There is no significant difference in tracer uptake between the ipsilateral region around the stroke and the contralateral region. Data are shown as means $\pm \mathrm{SD}$

number of more delayed events such as postischaemic inflammation [19]. The results of our study suggest that $\mathrm{CB}_{1}$ is involved in the inflammatory reaction rather than having an immediate effect on the inhibition of glutamate release, since no increase in tracer binding or in $\mathrm{CB}_{1}$ expression was detected by immunohistochemistry at the early time-point of $3.5 \mathrm{~h}$ after stroke.

Another striking finding of the current study was the ex vivo detection of $\mathrm{CB}_{1}{ }^{+}$cells inside the lesion 1 and 2 weeks 
a
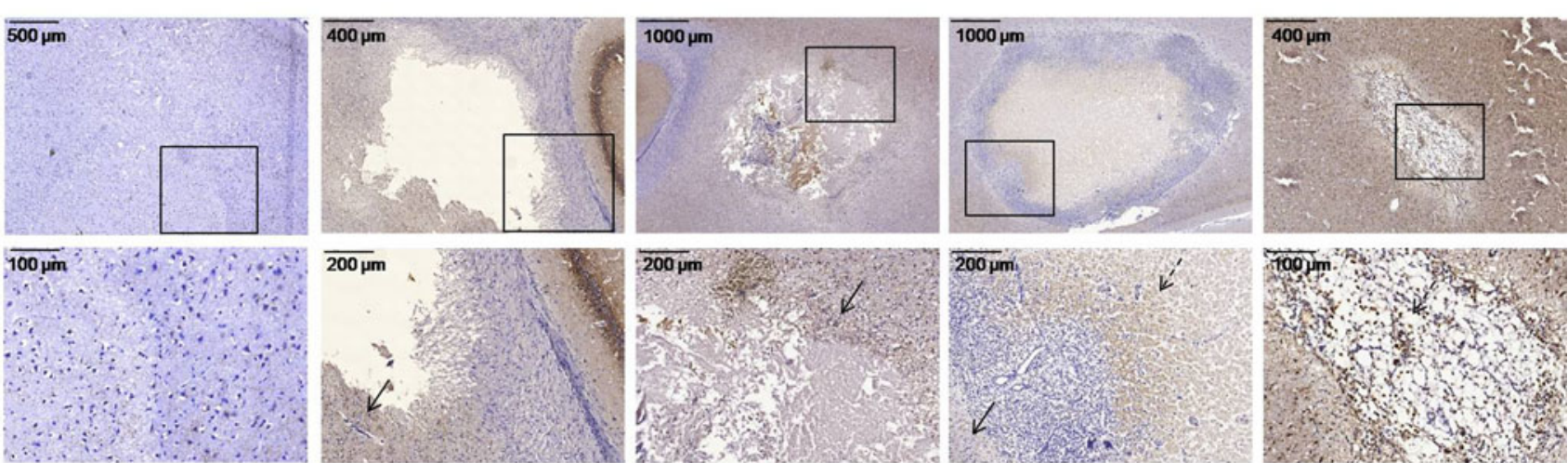

b

$1-3.5 h$

24h

72h

$1 w$

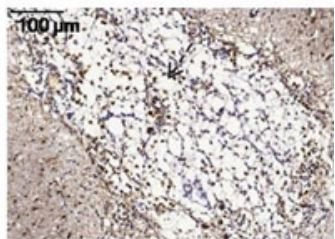

(1)
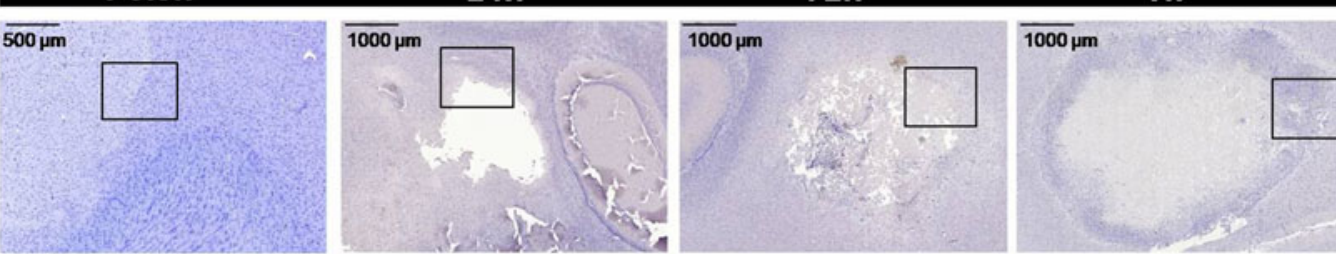

$2 w$
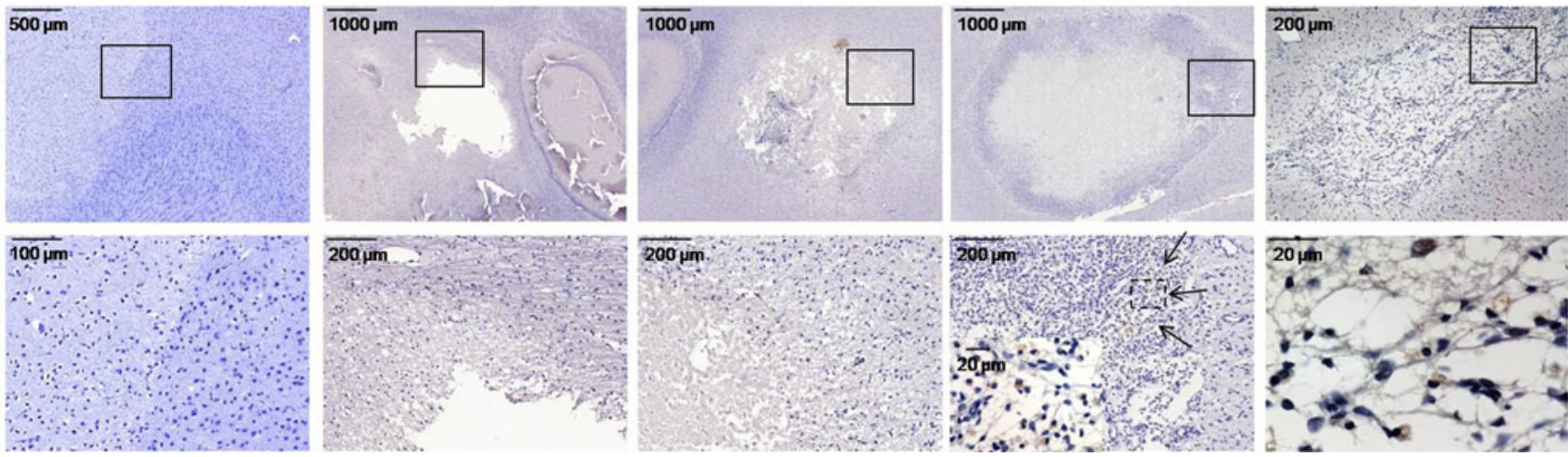

Fig. 6 Representative immunohistochemical staining for $\mathrm{CB}_{1}$ (a) and

cells. No increased $\mathrm{CB}_{1}$ expression is seen at $3.5 \mathrm{~h}$ after stroke. b Low $\mathrm{CB}_{2}$ (b) in stroke lesions 1-3.5 h, $24 \mathrm{~h}, 72 \mathrm{~h}$, and 1 and 2 weeks after surgery. a At $24 \mathrm{~h}$ until $72 \mathrm{~h}$ increased $\mathrm{CB}_{1}$ expression is seen around the stroke lesion. At 1 week $\mathrm{CB}_{1}{ }^{+}$cells are detected inside the lesion rim. At 2 weeks after surgery the lesion is fully covered with $\mathrm{CB}_{1}{ }^{+}$ levels of $\mathrm{CB}_{2}{ }^{+}$cells are seen starting 1 week after surgery. No $\mathrm{CB}_{2}{ }^{+}$ cells are seen at $1-3.5 \mathrm{~h}, 24 \mathrm{~h}$ and $72 \mathrm{~h}$ after surgery. Inset areas shown at higher magnification in the images below

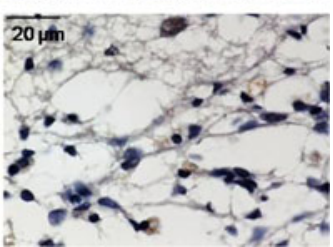

Fig. 7 Double

immunofluorescence staining of the stroke regions with anti$\mathrm{CB}_{2}$ (green) and anti-CD68 (red) antibodies 1 week after stroke. Only a minority of $\mathrm{CB}_{2}$ cells are positive for CD68 (white arrows $\mathrm{CB}_{2}^{+}$cells, yellow arrows $\mathrm{CB}_{2}^{+}$cells costained for $\mathrm{CD} 68$ )

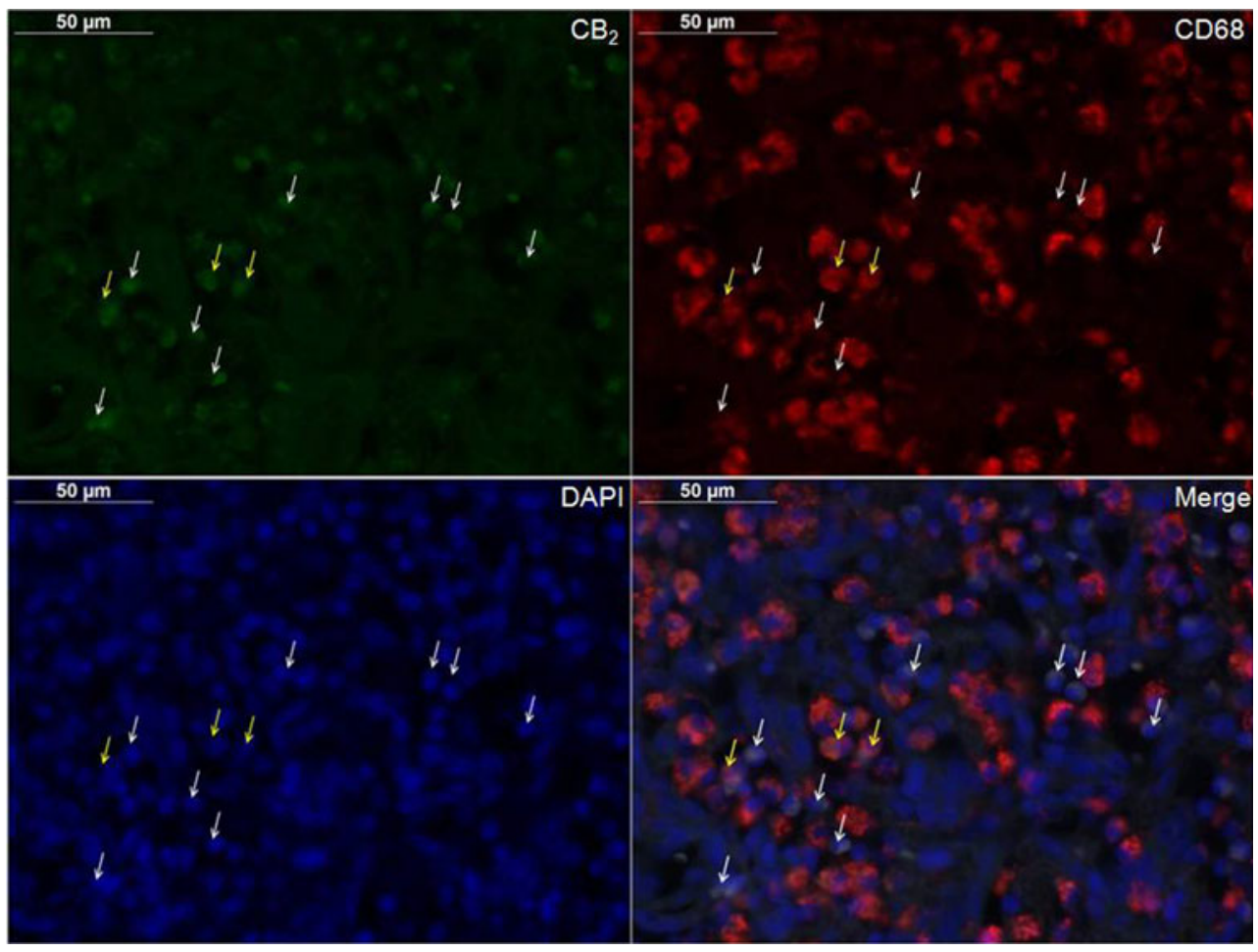


after stroke, filling the necrotic tissue. Indirectly, this process was also seen by $\left[{ }^{18} \mathrm{~F}\right] \mathrm{MK}-9470 \mathrm{PET}$ as the decrease in tracer binding present within the stroke lesion $24 \mathrm{~h}$ after surgery had almost disappeared 1 week after surgery (Fig. 2). This finding supports those of studies that have addressed the expression profile of $\mathrm{CB}_{1}$ in inflammatory cells such as lymphocytes, microglia/macrophages and astrocytes, which form a socalled glial scar and/or accumulate inside the lesion over time [32-34]. However, surprisingly, none of the $\mathrm{CB}_{1}{ }^{+}$or $\mathrm{CB}_{2}{ }^{+}$cells were $\mathrm{GFAP}^{+}$(GFAP is a cell-specific marker that distinguishes astrocytes from other glial cells) at any of the time-points. As only a proportion of these cells were $\mathrm{CD} 68^{+}$and as both $\mathrm{CB}_{1}$ and $\mathrm{CB}_{2}$ are expressed on $\mathrm{T}$ lymphocytes, where they mediate the immunomodulatory effects of cannabinoids on T-cell function [33], and based on the morphology of the cells, it is possible that the $\mathrm{CB}_{1}^{+}$or $\mathrm{CB}_{2}^{+}$cells accumulating inside and around the stroke region 1 week after stroke are $\mathrm{T}$ lymphocytes.

We also observed a $17 \%$ increase in $\mathrm{CB}_{1}$ binding in the ipsilateral insular cortex $24 \mathrm{~h}$ after stroke. Involvement of $\mathrm{CB}_{1}$ in the insular cortex in vivo in a rat model of stroke has not been found before. Nevertheless, this finding may support those of studies indicating that the insula plays putative role in motor recovery in stroke patients. Loubinoux et al. found better motor recovery, more specifically in handgrip strength and fingertapping speed, 1 year after stroke in patients with a higher early activation in the ipsilateral M1, S1, premotor cortex and insula using fMRI [35]. One caveat, however, is that no correction for partial volume effects was performed in our study.

Regarding the visualization of $\mathrm{CB}_{2}$ in the rats with photothrombotic stroke, no significant differences in uptake between the ipsilateral and contralateral hemispheres nor between the stroke and sham-operated animals were measured, even though some $\mathrm{CB}_{2}{ }^{+}$cells were detected ex vivo in the border zone of the lesion starting 1 week after surgery. An increase in $\mathrm{CB}_{2}$ expression has previously been exclusively described in models involving MCAO [4, 13, 15]. Ashton et al. showed clusters of $\mathrm{CB}_{2}$ and $\mathrm{CD}_{4} 5^{+}$microglia/ macrophages via immunohistochemistry and Western blot in the ischaemic penumbra at 3 days after MCAO until at least 7 days after surgery [15]. In addition, Zhang et al. measured a small decrease in $\mathrm{CB}_{2}$ mRNA expression during the first $3 \mathrm{~h}$ after ischaemia, but then a continued increase up to $24 \mathrm{~h}$, which was the latest time-point measured. An ex vivo increase in $\mathrm{CB}_{2}$ expression in the photothrombotic rat model of stroke has not been described before. Although the MCAO model is the model most used preclinically, we opted for the photothrombotic stroke model because an ischaemic lesion can be induced in any desired cortical area, with good reproducibility in lesion size and a high survival rate in comparison to the MCAO model. Since $\mathrm{CB}_{2}$ expression in activated microglia depends on the combination of cytokines and molecules encountered by these immune cells, the stroke model that is used may have a major influence on the results [36]. A photothrombotic stroke is followed by an almost immediate disruption of the bloodbrain barrier, vasogenic oedema, microvascular occlusions and a peripheral inflammatory response as early as 3 days after the insult [37]. In the MCAO model, macrophage activity starts after a delay of $1-5$ days and persists for a longer time [38]. However, our findings may in part also be explained by the low nanomolar affinity of $\left[{ }^{11} \mathrm{C}\right] \mathrm{NE} 40$ for human $\mathrm{CB}_{2}\left(K_{\mathrm{i}} 9.6 \mathrm{nM}\right)$. As the expression of $\mathrm{CB}_{2}$ in our model is rather limited, it is possible that $\mathrm{CB}_{2}$ radioligands with subnanomolar affinity are needed to be able to visualize the neuroinflammation. As a result $\left[{ }^{11} \mathrm{C}\right] \mathrm{NE} 40$ may not be sensitive enough to detect low concentrations of $\mathrm{CB}_{2}{ }^{+}$ cells in pathological conditions.

Although not shown by small-animal PET imaging, the presence of $\mathrm{CB}_{2}^{+}$cells shown by immunostaining - albeit modest - in this stroke model, does not refute a potential role of $\mathrm{CB}_{2}$ in inflammatory processes inherent to the pathophysiology of stroke.

\section{Conclusion}

A time-dependent increase in $\mathrm{CB}_{1}$ binding was present in the region surrounding photothrombotic stroke lesions $24 \mathrm{~h}$ and $72 \mathrm{~h}$ after the stroke event, extending to the surrounding insular cortex at $24 \mathrm{~h}$ after surgery. Normalization occurred within 1 week. No significant changes were detected in $\mathrm{CB}_{2}$ expression in vivo, although some $\mathrm{CB}_{2}{ }^{+}$cells were visible ex vivo. These results support pharmacological interventions targeting the subacute phase after stroke to further study the role of $\mathrm{CB}_{1}$ in the inflammatory response.

Acknowledgments Merck \& Co, Inc. is acknowledged for making available the $\left[{ }^{18} \mathrm{~F}\right] \mathrm{MK}-9470$ precursor. The authors are grateful to Jeanine Santermans, Kimy Emonds and Ellen Devos for their help with the immunohistochemical stainings, and to Peter Vermaelen and Ann Van Santvoort for small-animal PET scanning. Tjibbe de Groot and Dominique Vanderghinste are gratefully acknowledged for the radiopharmaceutical preparations. Caroline Vandeputte, Daisy van Veghel and Nele Evens are doctoral fellows of the Institute for the Promotion of Innovation through Science and Technology in Flanders (IWT Vlaanderen). Cindy Casteels is a postdoctoral fellow of the Flemish Fund for Scientific Research (FWO Vlaanderen). Koen Van Laere is senior clinical research fellow for the FWO Vlaanderen. This work was funded by Leuven University grants: MoSAIC CoE (Molecular Small Animal Imaging Center, Center of Excellence): EF/05/ 008, and OT/05/58.

Conflicts of interest None.

\section{References}

1. Flynn RW, MacWalter RS, Doney AS. The cost of cerebral ischaemia. Neuropharmacology. 2008;55:250-6.

2. Hossmann KA. Pathophysiology and therapy of experimental stroke. Cell Mol Neurobiol. 2006;26:1057-83. 
3. Mehta SL, Manhas N, Raghubir R. Molecular targets in cerebral ischemia for developing novel therapeutics. Brain Res Rev. 2007;54:34-66.

4. Ashton JC, Glass M. The cannabinoid CB2 receptor as a target for inflammation-dependent neurodegeneration. Curr Neuropharmacol. 2007;5:73-80.

5. Nagayama T, Sinor AD, Simon RP, Chen J, Graham SH, Jin K, et al. Cannabinoids and neuroprotection in global and focal cerebral ischemia and in neuronal cultures. J Neurosci. 1999;19:2987-95.

6. Howlett AC, Mukhopadhyay S, Norford DC. Endocannabinoids and reactive nitrogen and oxygen species in neuropathologies. $\mathrm{J}$ Neuroimmune Pharmacol. 2006;1:305-16.

7. Matsuda LA, Lolait SJ, Brownstein MJ, Young AC, Bonner TI. Structure of a cannabinoid receptor and functional expression of the cloned cDNA. Nature. 1990;346:561-4.

8. Munro S, Thomas KL, Abu-Shaar M. Molecular characterization of a peripheral receptor for cannabinoids. Nature. 1993;365:61-5.

9. Jin KL, Mao XO, Goldsmith PC, Greenberg DA. CB1 cannabinoid receptor induction in experimental stroke. Ann Neurol. 2000;48:257-61.

10. Parmentier-Batteur S, Jin K, Mao XO, Xie L, Greenberg DA. Increased severity of stroke in CB1 cannabinoid receptor knock-out mice. J Neurosci. 2002;22:9771-5.

11. Berger C, Schmid PC, Schabitz WR, Wolf M, Schwab S, Schmid $\mathrm{HH}$. Massive accumulation of $\mathrm{N}$-acylethanolamines after stroke. Cell signalling in acute cerebral ischemia? J Neurochem. 2004;88:1159-67.

12. Zhang M, Martin BR, Adler MW, Razdan RK, Jallo JI, Tuma RF. Cannabinoid $\mathrm{CB}(2)$ receptor activation decreases cerebral infarction in a mouse focal ischemia/reperfusion model. J Cereb Blood Flow Metab. 2007;27:1387-96.

13. Zhang M, Martin BR, Adler MW, Razdan RK, Ganea D, Tuma RF. Modulation of the balance between cannabinoid $\mathrm{CB}(1)$ and $\mathrm{CB}(2)$ receptor activation during cerebral ischemic/reperfusion injury. Neuroscience. 2008;152:753-60.

14. Murikinati S, Juttler E, Keinert T, Ridder DA, Muhammad S, Waibler $\mathrm{Z}$, et al. Activation of cannabinoid 2 receptors protects against cerebral ischemia by inhibiting neutrophil recruitment. FASEB J. 2010;24:788-98.

15. Ashton JC, Rahman RM, Nair SM, Sutherland BA, Glass M, Appleton I. Cerebral hypoxia-ischemia and middle cerebral artery occlusion induce expression of the cannabinoid CB2 receptor in the brain. Neurosci Lett. 2007;412:114-7.

16. Burns HD, Van Laere K, Sanabria-Bohorquez S, Hamill TG, Bormans G, Eng WS, et al. [18F]MK-9470, a positron emission tomography (PET) tracer for in vivo human PET brain imaging of the cannabinoid1 receptor. Proc Natl Acad Sci U S A. 2007;104:9800-5.

17. Evens N, Muccioli GG, Houbrechts N, Lambert DM, Verbruggen AM, Van Laere K, et al. Synthesis and biological evaluation of carbon-11- and fluorine-18-labeled 2-oxoquinoline derivatives for type 2 cannabinoid receptor positron emission tomography imaging. Nucl Med Biol. 2009;36:455-65.

18. Evens N, Vandeputte C, Coolen C, Janssen P, Sciot R, Baekelandt $\mathrm{V}$, et al. Preclinical evaluation of [(11)C]NE40, a type 2 cannabinoid receptor PET tracer. Nucl Med Biol. 2012;39:389-99.

19. Dirnagl U, Iadecola C, Moskowitz MA. Pathobiology of ischaemic stroke: an integrated view. Trends Neurosci. 1999;22:391-7.

20. Watson BD, Dietrich WD, Busto R, Wachtel MS, Ginsberg MD. Induction of reproducible brain infarction by photochemically initiated thrombosis. Ann Neurol. 1985;17:497-504.

21. Casteels C, Bormans G, Van Laere K. The effect of anaesthesia on [(18)F]MK-9470 binding to the type 1 cannabinoid receptor in the rat brain. Eur J Nucl Med Mol Imaging. 2010;37:1164-73.
22. Need AB, Davis RJ, Alexander-Chacko JT, Eastwood B, Chernet E, Phebus LA, et al. The relationship of in vivo central CB1 receptor occupancy to changes in cortical monoamine release and feeding elicited by CB1 receptor antagonists in rats. Psychopharmacology (Berl). 2006;184:26-35.

23. Terry GE, Liow JS, Zoghbi SS, Hirvonen J, Farris AG, Lerner A, et al. Quantitation of cannabinoid CB1 receptors in healthy human brain using positron emission tomography and an inverse agonist radioligand. Neuroimage. 2009;48:362-70.

24. Sanabria-Bohorquez SM, Hamill TG, Goffin K, De Lepeleire I, Bormans G, Burns HD, et al. Kinetic analysis of the cannabinoid-1 receptor PET tracer [(18)F]MK-9470 in human brain. Eur J Nucl Med Mol Imaging. 2010;37:920-33.

25. Casteels C, Koole M, Celen S, Bormans G, Van Laere K. Preclinical evaluation and quantification of [18F]MK-9470 as a radioligand for PET imaging of the type 1 cannabinoid receptor in rat brain. Eur J Nucl Med Mol Imaging. 2012;39:1467-77.

26. Nunez E, Benito C, Pazos MR, Barbachano A, Fajardo O, Gonzalez $\mathrm{S}$, et al. Cannabinoid $\mathrm{CB} 2$ receptors are expressed by perivascular microglial cells in the human brain: an immunohistochemical study. Synapse. 2004;53:208-13.

27. Casteels C, Vermaelen P, Nuyts J, Van Der Linden A, Baekelandt V, Mortelmans L, et al. Construction and evaluation of multitracer small-animal PET probabilistic atlases for voxel-based functional mapping of the rat brain. J Nucl Med. 2006;47:1858-66.

28. van Kuyck K, Casteels C, Vermaelen P, Bormans G, Nuttin B, Van Laere K. Motor- and food-related metabolic cerebral changes in the activity-based rat model for anorexia nervosa: a voxel-based microPET study. Neuroimage. 2007;35:214-21.

29. Le Foll B, Goldberg SR. Cannabinoid CB1 receptor antagonists as promising new medications for drug dependence. J Pharmacol Exp Ther. 2005;312:875-83.

30. Marsicano G, Goodenough S, Monory K, Hermann H, Eder M, Cannich A, et al. CB1 cannabinoid receptors and on-demand defense against excitotoxicity. Science. 2003;302:84-8.

31. Garcia DE, Li B, Garcia-Ferreiro RE, Hernandez-Ochoa EO, Yan $\mathrm{K}$, Gautam N, et al. G-protein beta-subunit specificity in the fast membrane-delimited inhibition of $\mathrm{Ca} 2+$ channels. J Neurosci. 1998;18:9163-70.

32. Fawcett JW, Asher RA. The glial scar and central nervous system repair. Brain Res Bull. 1999;49:377-91.

33. Rossi B, Zenaro E, Angiari S, Ottoboni L, Bach S, Piccio L, et al. Inverse agonism of cannabinoid $\mathrm{CB} 1$ receptor blocks the adhesion of encephalitogenic $\mathrm{T}$ cells in inflamed brain venules by a protein kinase A-dependent mechanism. J Neuroimmunol. 2011;233:97105.

34. Borner C, Hollt V, Sebald W, Kraus J. Transcriptional regulation of the cannabinoid receptor type 1 gene in T cells by cannabinoids. J Leukoc Biol. 2007;81:336-43.

35. Loubinoux I, Dechaumont-Palacin S, Castel-Lacanal E, De Boissezon $\mathrm{X}$, Marque $\mathrm{P}$, Pariente J, et al. Prognostic value of FMRI in recovery of hand function in subcortical stroke patients. Cereb Cortex. 2007:17:2980-7.

36. Stella N. Cannabinoid and cannabinoid-like receptors in microglia, astrocytes, and astrocytomas. Glia. 2010;58:1017-30.

37. Schroeter M, Jander S, Huitinga I, Witte OW, Stoll G. Phagocytic response in photochemically induced infarction of rat cerebral cortex. The role of resident microglia. Stroke. 1997;28:382-6.

38. Kato H, Kogure K, Liu XH, Araki T, Itoyama Y. Progressive expression of immunomolecules on activated microglia and invading leukocytes following focal cerebral ischemia in the rat. Brain Res. 1996;734:203-12. 